\title{
EVALUASI SEBARAN LOGAM Hg, Cd, Cr DAN Co DALAM CUPLIKAN AIR, SEDIMEN DAN ENCENG GONDOK DI LOKASI PERAIRAN SURABAYA III
}

\author{
Agus Taftazani, Sumining dan Muzakky \\ Puslitbang Teknologi Maju BATAN, Yogyakarta
}

\begin{abstract}
ABSTRAK
EVALUASI SEBARAN LOGAM Hg. Cd, Cr dan Co DALAM CUPLIKAN AIR, SEDIMEN DAN ENCENG GONDOK DI LOKASI PERAIRAN SURABAYA III. Telah dilakukan evaluasi sebaran kadar logam berat dalam cuplikan lingkungan perairan sungai Surabaya ke III dengan metode Analisis Aktivasi Neutron (AAN). Cuplikan diambil dari sungai Morokrembangan dan sungai Kenjeran masing-masing dari 6 stasiun pengambilan. Cuplikan air, sedimen dan enceng gondok dihaluskan, dihomogenkan kemudian diradiasi dengan flux netron $1,05 \times 10^{11} \mathrm{n} \cdot \mathrm{cm}^{-2} . d t^{-1}$ selama $12 \mathrm{jam}$. Diperoleh data, dalam semua cuplikan terdeteksi unsur ${ }^{197} \mathrm{Hg}(77,6 \mathrm{keV}),{ }^{31} \mathrm{Cr}(320 \mathrm{keV}),{ }^{115} \mathrm{Cd}(527,7$ $\mathrm{keV})$ dan ${ }^{60} \mathrm{Co}(1173,1 \mathrm{keV})$. Kadar logam berat $\mathrm{Hg}$, Cd, Cr dan Co dalam air kedua sungai sudah melampaui batas ambang baku mutu Kep-02/MEN KLH/I/1988, sedangkan kadar logam berat dalam sedimen dan enceng gondok belum ada baku mutu dari Men Kesehatan atau Men KLH. Harga Faktor Distribusi $\left(F_{p}\right)$ sedimen > Faklor Bioakumulasi $\left(F_{n}\right)$ enceng gondok untuk unsur $\mathrm{Hg}, \mathrm{Cd}, \mathrm{Cr}$ dan Co.
\end{abstract}

\section{ABSTRACT}

THIRD EVALUATION OF Hg, Cd, Cr and Co ELEMENTS DISTRIBUTION IN WATER, SEDIMENT AND WATER HYACINTH FROM SURABAYA RIVER. Evaluation of heavy metal elements content of environmetal samples of Kenjeran and Morokrembangan river Surabaya using Neutron Activation Analysis (NAA) Technique have been done. The environment samples i.e. water, sedimen and water hyacinth have been taken from 6 sampling stations at Morokrembangan and Kenjeran river. The samples have been grinded, homogenized and 12 hours irradiated by $1.05 \times 1011$ n.cm-2.sec-1 neutron flux. The elements ${ }^{197} \mathrm{Hg}(77,6 \mathrm{keV}),{ }^{31} \mathrm{Cr}(320 \mathrm{keV}),{ }^{115} \mathrm{Cd}(527,7 \mathrm{keV}) \mathrm{dan}{ }^{60} \mathrm{Co}$ $(1173,1 \mathrm{keV})$ in all samples have been detected. The result showed that the concentration of $\mathrm{Hg}$. Cd, $\mathrm{Cr}$ and $\mathrm{Co}$ of water samples were higher than that of maximum permissible concentration for D-class water according to the threshold value decided by Environmetal Minister, Act. Kep.02/MENKLH/I/1988. The concentration of those metals in sediment and water hyacinth samples cannot be evaluated, because the regulation related to the maximum permissible concentration of the heavy metals decided by Indonesian Health Minister or Environmental Minister Act are not available. The data showed that the distribution factor $\left(F_{d}\right)$ is greater than that the bioaccumulation factor $\left(F_{B}\right)$ for $\mathrm{Hg}, \mathrm{Cd}$, Cr and Co elements.

\section{PENDAHULUAN}

L ogam berat yang masuk kedalam lingkungan perairan dapat ditemukan dalam air, sedimen, dan organisme yang hidup di daerah tcrsebut, sehingga air, sedimen dan organisme hidup dapat digunakan sebagai indikator pencemaran laut ${ }^{(1)}$.

Setiap perairan memiliki kapasitas terima (receving capacity) yang terbatas terhadap bahan pencemar. Dengan adanya peningkatan buangan air limbah yang mengandung senyawa logam bcrat beracun, cepat atau lambat hal tersebut akan mengakibatkan kerusakan ekosistem perairan. Hal ini karena logam berat sukar mengalami proses pelapukan, baik secara kimia, fisika maupun biologis.

Adanya limbah industri, bila kurang sempurna pengolahannya akan menjadi faktor yang mcrugikan bagi lingkungan. Demikan juga halnya perkembangan kawasan industri dan pemukiman Surabaya, khususnya daerah perairan pantai sungai di Morokrembangan dan di Kenjeran. Limbah penduduk dengan segala kegiatanya dan 
industri sepanjang sungai Surabaya berupa polutan padat atau cair baik sebagai senyawa organik beracun, logam berat beracun yang masuk ke perairan sungai akhirnya mengalir ke pantai Morokrembangan dan pantai Kenjeran. Wilayah pesisir merupakan tempat bermuaranya Sungai Morokrembangan dan Sungai Kenjeran serta menjadi tempat buangan limbah domestik ${ }^{(2)}$.

Dari tinjauan berbagai pustaka pencemaran yang dihasilkan dari logam berat sampai tingkat tertentu dapat mengganggu kesehatan manusia. Masalah yang ditimbulkan oleh logam berat ini cukup rumit, karena logam berat mempunyai sifat-sifat beracun, tidak dapat dirombak atau hancurkan oleh organisme hidup, dapat diakumulasi dalam tubuh organisme termasuk manusia, baik secara langsung maupun tidak langsung. Logam berat $\mathrm{Hg}$. Cd, $\mathrm{Cr}$ adalah termasuk logam sangat beracun (dapat mengakibatkan kematian atau gangguan kesehatan yang tidak pulih dalam waktu singkat), sedang logam berat Co sifat racunnya moderat (dapat mengakibatkan gangguan kesehatan baik yang dapat pulih maupun yang tidak dapat pulih dalam waktu relatif lama) ${ }^{(3)}$.

Penelitian yang dilakukan oleh Balai Teknik Kesehatan Lingkungan (BTKL) Surabaya di kawasan Pantai Kenjeran pada tahun $1997^{(4)}$ menegaskan bahwa kandungan logam berat merkuri, tembaga dan timbal dalam tubuh ikan sudah melebihi ambang batas yang diperbolehkan oleh WHO dan FAO untuk dikomsumsi. Sebagai contoh, kadar $\mathrm{Hg}$ rata-rata dalam ikan tatengkek untuk seluruh wilayah Kecamatan Kenjeran dan Sukolilo sudah mencapai 0,573 ppm. Bahkan, khusus Kelurahan Kenjeran, kadar Hg dalam kerang darah pernah mencapai 1,273 ppm. Demikian juga hasil penelitian Badan Perencanaan Pembangunan Daerah Tingkat I Jawa Timur tahun 1998 melaporkan bahwa ikan dan kerang di wilayah kelurahan Sukolilo, Kecamatan Kenjeran dan sekitar Kotamadia
Surabaya mengandung merkuri, tembaga dan timbal ${ }^{(5)}$. Penelitian yang dilakukan oleh Agus Taftazani dkk. pada tahun $1999^{(6)}$ melaporkan bahwa kadar logam Co pada berbagai jenis ikan di kali Surabaya berkisar antara 0,099 sampai dengan 0,441 $\mu \mathrm{glg}$, begitu pula kadar $\mathrm{Cr}$ berkisar antara 7,195 sampai dengan 15,801 $\mu \mathrm{g} / \mathrm{g}$. Kadar logam Co pada air di kali Surabaya berkisar antara 0,016 sampai 0,039 $\mu \mathrm{g} / \mathrm{ml}$, begitu pula kadar Cr berkisar antara 0,094 sampai 0,491 $\mu \mathrm{g} / \mathrm{ml}$ dan kadar Hg berkisar antara 0,684 sampai dengan 36,703 $\mu \mathrm{g} / \mathrm{ml}$ tergantung pada lokasinya. Penelitian Agus Taftazani pada tahun $2001^{(7)}$. menyatakan air pantai Kenjeran telah tercemar logam berat $\mathrm{Hg}$ dan $\mathrm{Cr}$, sedang cuplikan kerang dan sedimen telah tercemar logam berat $\mathrm{Hg}$. $\mathrm{Cr}$, Cd dan Co, sedang ikan telah tercemar dua unsur Hg dan Cr.

Dalam pengendalian dan pemantauan dampak lingkungan adalah perlu dilakukan analisis unsur-unsur dalam cuplikan lingkungan yang tercemar oleh limbah industri, terutama kandungan logam berat, radionuklida maupun senyawa kimia berbahaya lainnya. Analisis tersebut diperlukan untuk mengevaluasi tingkat pencemaran yang terjadi.

Identifikasi dan pengukuran logam berat $\mathrm{Hg}, \mathrm{Cd}, \mathrm{Cr}$ dan Co dalam cuplikan penelitian ini, dilakukan dengan metode Analisis Aktivasi Neutron (AAN). Cuplikan yang dianalisis diiradiasi dengan menggunakan suatu sumber neutron, inti atom unsurunsur yang berada dalam cuplikan atom akan menangkap neutron dan berubah menjadi radioaktif (pemancar $\gamma$ ). Sinar $\gamma$ yang dipancarkan oleh beberapa unsur dalam cuplikan yang telah diiradiasi dapat dianalis dengan spektrometri sinar $\gamma$. Analisis kualitatif dilakukan berdasarkan penentuan energi sinar $\gamma$, sedangkan analisis kuantitatif dilakukan dengan menentukan intensitasnya ${ }^{(8)}$.

Tujuan penelitian adalah untuk mengetahui kadar logam $\mathrm{Cr}$, Co, Cd dan $\mathrm{Hg}$ 
yang terdapat dalam air, sedimen dan enceng gondok, di Sungai Morokrembangan dan Sungai Kenjcran, Surabaya dengan metode AAN sebagai kelanjutan penelitian cuplikan dari perairan pantai Kenjeran pada tahun $2001^{(7)}$. Membandingkan konsentrasi kadar logam berat $\mathrm{Cr}$, Co, Cd dan Hg dalam air sungai dengan batas ambang air golongan D pada baku mutu Kep-02/MEN $\mathrm{KLH} / \mathrm{I} / 1988^{(9)}$. Menentukan faktor bioakumulasi (FB) $\mathrm{Cr}$, Co, $\mathrm{Cd}$ dan $\mathrm{Hg}$ dalam enceng gondok dan faktor distribusi (FD) sedimen terhadap air sungai yang dapat dijadikan indikator kualitas perairan.

\section{TATA KERJA}

\section{Peralatan yang dipakai ${ }^{(2)}$}

Satu perangkat alat sampling dan perahu motor, satu perangkat alat preparasi suhu panas dan dingin (Freeze drying), Fasilitas Lazy Susan Reaktor Riset Kartini (flux neutron $1,05 \times 10^{11}$ n.cm ${ }^{-2} \cdot$ det $^{-1}$, satu perangkat Spektrometer $\gamma$ dengan detektor Ge(Li) dan MCA Spectrum Master ORTEC $92 X$, dengan software Maestro II, dsb.

\section{Bahan yang dipakai}

Cuplikan bahan penelitian air, sedimen dan enceng gondok dari sungai Surabaya, Sumber standar multi gamma (Eu - 152) untuk kalibrasi alat, nitrogen cair untuk preparasi cuplikan, SRM 2704 (Buffalo Rivers Sediment), cellulosa powder, standar sekunder unsur $\mathrm{Hg}$, Cr, Co, Cd dari Fisher untuk analisis kuantitatif.

\section{Pengambilan Cuplikan}

Pada pengambilan cuplikan untuk penelitian ini digunakan metode cuplikan sesaat (grab sample) dan cuplikan gabungan tempat (integrated sample) ${ }^{(10)}$ pada 6 lokasi stasiun pengambilan.

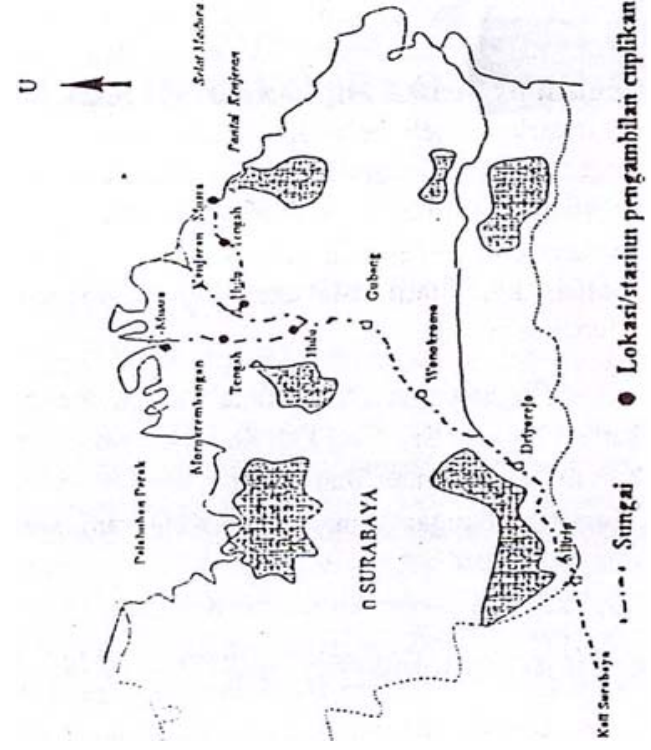

Gambar 1. Peta lokasi pengambilan cuplikan di perairan sungai Surabaya

\section{Prosedur penyiapan enceng gondok ${ }^{(6)}$}

Enceng gondok diambil di 3 titik (hulu, tengah dan muara sungai Kenjeran maupun Morokrembangan, (lihat Gambar 1) masingmasing sebanyak $2 \mathrm{~kg}$ dicuci dengan air setempat kemudian bagian akar, batang dan daun dicampur menjadi satu kemudian diberi nitrogen cair, ditumbuk sampai halus dan selanjutnya dikeringkan dalam suhu rendah freeze drying selama 2 x 24 jam, kemudian dihomogenkan dan diayak sampai lolos 100 mesh, ditimbang guna mengetahui berat akhirnya. Cuplikan diambil 0,1 - 0,2 gr dimasukkan dalam vial yang bersih, cupilkan siap diiradiasi.

\section{Prosedur penyiapan Sedimen ${ }^{(2)}$}

Cuplikan sedimen diambil sebanyak 2 kg dari setiap titik pengambilan enceng gondok tersebut di atas, kemudian sedimen diangin-anginkan dalam nampan di ruang laboratorium dan sambil dibersihkan dari plastik, akar dan kerikil. Sedimen kering ditumbuk sampai lolos 100 mesh dan dihomogenkan, kemudian diambil cuplikan 0,1 - 0,2 gr dimasukkan dalam vial, cuplikan siap diiradiasi. 


\section{Prosedur penyiapan air sungai ${ }^{(2)}$}

Air sungai diambil dari Sungai Morokrembangan dan Sungai Kenjeran. Air diambil sebanyak 5 liter pada lokasi dimana sedimen dan enceng gondok diambil. Diambil air sungai 1 liter, kemudian dipekatkan/dipanaskan dalam wadah porselin sehingga volumenya menjadi 50 ml. Hasil dari pemekatan tersebut diambil 2 $\mathrm{ml}$ dan dimasukkan dalam vial ukuran $3 \mathrm{ml}$ untuk diiradiasi bersama-sama dengan SRM dan standar sekunder. Untuk analisis Hg, cuplikan disiapkan tanpa pemekatan.

\section{Prosedur iradiasi $^{(2)}$}

lradiasi dilakukan di reaktor riset Kartini, cuplikan air $2 \mathrm{ml}$, sedimen 0,1 gr, enceng gondok 0,1 gr, masing-masing 3 kali (triple), diradiasi bersama-sama SRM (river sediment) dan standar sekunder campuran selama 12 jam dengan fluks neutron $1,05 \times 10^{11} \mathrm{n} \cdot \mathrm{cm}^{-2}$.det ${ }^{-1}$ di lokasi Lazy Susan dan didinginkan selama 5-20 hari (tergantung dari jenis unsur yang dianalisis atau waktu paruh $\mathrm{T}^{1 / 2}$ ). Setelah itu cuplikan, SRM dan standar sekunder dicacah dengan spektrometer gamma, dihitung besar spektrumnya kemudian dibandingkan antara spektrum cuplikan dan standar untuk menentukan kadar unsur logam berat dalam cuplikan.

\section{Analisis Kuantitatif ${ }^{(2)}$}

Setelah diketahui berapa jenis unsur logam yang terdapat dalam cuplikan secara kualilatif (energi spesifik $\gamma$-nya), selanjutnya dilakukan penentuan secara kuantitatif. Analisis kuantitatif ini dilakukan dengan cara relatif yaitu membandingkan kadar unsur-unsur dalan cuplikan dengan kadar unsur-unsur yang ada dalam standar.

Standar dan cuplikan diiradiasi dalam waktu dan tempat yang sama. Untuk menentukan kadar suatu unsur dalam cuplikan cukup menggunakan perbandingan antara cacah yang dihasilkan cuplikan dengan cacah standar. Selanjutnya kadar dari unsur-unsur dapat dihitung dengan menggunakan rumus sebagai berikut : kadar unsur dalam cuplikan:

$\mathrm{Wc}=\frac{\text { Cps cuplikan }}{\text { Cps standar }} \times \mathrm{Ws}$

Wc $=$ kadar unsur yang diamati dalam cuplikan

Ws = kadar unsur yang diamati dalam standar sekunder

Cps = cacah per sekon dari cuplikan (atau standar)

Cps dihitung dengan rumus sebagai berikut :

Cps $=\frac{\text { Netto }}{\mathrm{t}_{\text {cacah }}}$

Netto = hasil pencacahan selama waktu pencacahan (selama $\mathrm{t}_{\text {cacah }}$ )

$\mathrm{t}_{\mathrm{cacah}}=$ waktu cacah selama pencacahan (detik)

Untuk menghitung faktor bioakumulasi $\left(\mathrm{F}_{\mathrm{B}}\right)$ dan faktor distribusi $\left(\mathrm{F}_{\mathrm{D}}\right)$ digunakan rumus :

$\mathrm{FB}=\frac{\mathrm{Cb}}{\mathrm{Ca}}$ dan $\mathrm{FD}=\frac{\mathrm{Cs}}{\mathrm{Ca}}$

Keterangan :

$\mathrm{F}_{\mathrm{B}}=$ faktor bioakumulasi (ml/g)

$\mathrm{Cb}=$ Konsentrasi biota (eceng gondok,

$\mu \mathrm{g} / \mathrm{g})$

$\mathrm{F}_{\mathrm{D}}=$ faktor distribusi ( $\left.\mathrm{ml} / \mathrm{g}\right)$

$\mathrm{Cs}=$ Konsentrasi sedimen $(\mu \mathrm{g} / \mathrm{g})$

$\mathrm{Ca}=$ Konsentrasi air $(\mu \mathrm{g} / \mathrm{g})$

\section{HASIL DAN PEMBAHASAN}

\section{Kalibrasi dan Analisis Kualitatif ${ }^{(8)}$}

Kalibrasi tenaga Spektrometer $\gamma$ dilakukan dengan radionuklida standar sumber multigamma ${ }^{152} \mathrm{Eu}$ sehingga didapat suatu garis linier yang merupakan kurva kalibrasi tenaga dengan persamaan $\mathrm{Y}=$ $0,502 \mathrm{X}$ - 0,805. Setelah mendapat harga tenaga (E) kemudian dicocokkan dengan tabel isotop (Erdtmann dan Soyka 1979) ${ }^{(11)}$ maka akan diketahui unsur apa saja yang ada pada cuplikan tersebut (Tabel 1).

Unsur-unsur yang terdeteksi dalam cuplikan air, sedimen dan enceng gondok yang berasal dari Sungai Kenjeran dan Sungai Morokrembangan Surabaya dengan metode AAN cukup beragam, yaitu: $\mathrm{Hg}$, Ce, $\mathrm{Cr}, \mathrm{Au}, \mathrm{Cd}, \mathrm{Br}, \mathrm{Se}, \mathrm{Fe}, \mathrm{Zn}, \mathrm{Co}$, Ca dan $\mathrm{Na}$ 
(Tabel 1). Khusus unsur Aurum hanya terdeteksi dalam cuplikan dari Sungai Kenjeran sehingga perlu diteliti lagi apakah ada kaitannya dengan unsur $\mathrm{Hg}$ yang digunakan untuk pengolahan tambang emas di sepanjang sungai Kenjeran. Tabel 1 menunjukkan terdeteksinya berbagai jenis logam maka lokasi tersebut perlu dijaga keseimbangan ekosistemnya, terutama peningkatan kadar unsur-unsur logam berat dan beracun akibat kegiatan industri, rumah tangga dan atau rumah sakit sepanjang ke dua sungai tersebut.

Tabel 1. Data kualitatif logam yang terdeteksi dalam air, sedimen dan enceng gondok dari Muara, Tengah dan Hulu perairan Sungai Kenjeran dan Morokrembangan. Waktu iradiasi 12 jam, flux neutron $1,05 \times 10^{11} \mathrm{n} \cdot \mathrm{cm}^{-2} \cdot \mathrm{dt}^{-1}$ (Lazy Susan), waktu cacah 300 detik.

\begin{tabular}{|c|c|c|c|c|c|c|c|c|c|c|c|c|c|}
\hline \multicolumn{3}{|c|}{ ISOTOP } & $\mathrm{Hg}-197$ & Ce-141 & Cr-31 & Au-198 & Cd-115 & $\mathrm{Br}-32$ & Sc-46 & Fe-59 & Zn-65 & Co-60 & Ca-47 \\
\hline \multicolumn{3}{|c|}{ TENAGA (keV) } & 77.6 & 145.4 & 320 & 411.8 & 527.7 & 554.3 & 889.4 & 1098.6 & 1115.4 & 1173.1 & 1296.9 \\
\hline \multicolumn{3}{|c|}{ WAKTU PARUH, T } & 65 jam & $32.5 \mathrm{hr}$ & $27.8 \mathrm{hr}$ & $2,70 \mathrm{hr}$ & 53 jam & 35,87 jam & $83,9 \mathrm{hr}$ & $45,1 \mathrm{hr}$ & $265 \mathrm{hr}$ & 5,24 th & $4.7 \mathrm{hr}$ \\
\hline \multirow{9}{*}{ 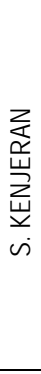 } & \multirow{3}{*}{ Air } & MK & $\mathrm{T}$ & $\mathrm{T}$ & $\mathrm{T}$ & $\mathrm{TI}$ & $\mathrm{T}$ & $\mathrm{T}$ & $\mathrm{T}$ & $\mathrm{T}$ & $\mathrm{T}$ & $\mathrm{T}$ & $T$ \\
\hline & & TK & $\mathrm{T}$ & $\mathrm{T}$ & $\mathrm{T}$ & $\mathrm{T}$ & $\mathrm{T}$ & $\mathrm{T}$ & $\mathrm{T}$ & $\mathrm{T}$ & $\mathrm{T}$ & $\mathrm{T}$ & $\mathrm{TI}$ \\
\hline & & HK & $\mathrm{T}$ & $\mathrm{T}$ & $\mathrm{T}$ & $\mathrm{T}$ & $\mathrm{T}$ & $\mathrm{T}$ & $\mathrm{T}$ & $\mathrm{T}$ & $\mathrm{T}$ & $\mathrm{T}$ & $\mathrm{T}$ \\
\hline & \multirow{3}{*}{ Sedimen } & MK & $\mathrm{T}$ & $\mathrm{T}$ & $\mathrm{T}$ & $\mathrm{T}$ & $\mathrm{T}$ & $\mathrm{T}$ & $\mathrm{T}$ & $\mathrm{T}$ & $\mathrm{T}$ & $\mathrm{T}$ & $\mathrm{T}$ \\
\hline & & TK & $\mathrm{T}$ & $\mathrm{T}$ & $\mathrm{T}$ & $\mathrm{T}$ & $\mathrm{T}$ & $\mathrm{T}$ & $\mathrm{T}$ & $\mathrm{T}$ & $\mathrm{T}$ & $\mathrm{T}$ & $\mathrm{T}$ \\
\hline & & $\mathrm{HK}$ & $\mathrm{T}$ & $\mathrm{T}$ & $\mathrm{T}$ & $\mathrm{T}$ & $\mathrm{T}$ & $T$ & $\mathrm{~T}$ & $T$ & $T$ & $T$ & $T$ \\
\hline & \multirow{3}{*}{$\begin{array}{l}\text { Enceng } \\
\text { gondok }\end{array}$} & MK & $\mathrm{T}$ & $\mathrm{T}$ & $\mathrm{T}$ & $\mathrm{T}$ & $\mathrm{T}$ & $\mathrm{T}$ & $\mathrm{T}$ & $\mathrm{T}$ & $\mathrm{T}$ & $\mathrm{T}$ & $\mathrm{T}$ \\
\hline & & HK & $\mathrm{T}$ & $\mathrm{T}$ & $\mathrm{T}$ & $\mathrm{T}$ & $\mathrm{T}$ & $\mathrm{T}$ & $\mathrm{T}$ & $\mathrm{T}$ & $\mathrm{T}$ & $\mathrm{T}$ & $\mathrm{T}$ \\
\hline & & TK & $\mathrm{T}$ & $\mathrm{T}$ & $\mathrm{T}$ & $\mathrm{T}$ & $T$ & $T$ & $\mathrm{~T}$ & $\mathrm{~T}$ & $\mathrm{~T}$ & $\mathrm{~T}$ & $T$ \\
\hline \multirow{9}{*}{ 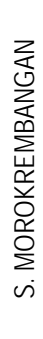 } & \multirow{3}{*}{ Air } & MM & $\mathrm{T}$ & $\mathrm{T}$ & $\mathrm{T}$ & $\mathrm{Tt}$ & $\mathrm{T}$ & $T$ & $\mathrm{~T}$ & $\mathrm{~T}$ & $T$ & $\mathrm{~T}$ & $\mathrm{TI}$ \\
\hline & & TM & $\mathrm{T}$ & $\mathrm{T}$ & $\mathrm{T}$ & $\mathrm{Tt}$ & $T$ & $T$ & $T$ & $T$ & $T$ & $T$ & $T$ \\
\hline & & $\mathrm{HM}$ & $\mathrm{T}$ & $\mathrm{Tt}$ & $\mathrm{T}$ & $\mathrm{Tt}$ & $\mathrm{T}$ & $T$ & $\mathrm{~T}$ & $\mathrm{~T}$ & $\mathrm{~T}$ & $\mathrm{~T}$ & $\mathrm{~T}$ \\
\hline & \multirow{3}{*}{ Sedimen } & MM & $\mathrm{T}$ & $\mathrm{T}$ & $\mathrm{T}$ & $\mathrm{Tt}$ & $\mathrm{T}$ & $\mathrm{T}$ & $\mathrm{T}$ & $\mathrm{T}$ & $\mathrm{T}$ & $\mathrm{T}$ & $\mathrm{TI}$ \\
\hline & & TM & $\mathrm{T}$ & $\mathrm{T}$ & $\mathrm{T}$ & $\mathrm{Tt}$ & $\mathrm{T}$ & $T$ & $\mathrm{~T}$ & $\mathrm{~T}$ & $\mathrm{~T}$ & $\mathrm{~T}$ & $\mathrm{TI}$ \\
\hline & & $\mathrm{HM}$ & $\mathrm{T}$ & $\mathrm{T}$ & $\mathrm{T}$ & $\mathrm{Tt}$ & $\mathrm{T}$ & $T$ & $T$ & $\mathrm{~T}$ & $\mathrm{~T}$ & $\mathrm{~T}$ & $\mathrm{~T}$ \\
\hline & \multirow{3}{*}{$\begin{array}{l}\text { Enceng } \\
\text { gondok }\end{array}$} & MM & $x$ & $x$ & $x$ & $x$ & $x$ & $x$ & $x$ & $x$ & $x$ & $x$ & $x$ \\
\hline & & HM & $\mathrm{T}$ & $\mathrm{T}$ & $\mathrm{T}$ & $\mathrm{Tt}$ & $\mathrm{T}$ & $\mathrm{T}$ & $\mathrm{T}$ & $\mathrm{T}$ & $\mathrm{T}$ & $\mathrm{T}$ & $\mathrm{TI}$ \\
\hline & & TM & $\mathrm{T}$ & $\mathrm{T}$ & $\mathrm{T}$ & $\mathrm{Tt}$ & $\mathrm{T}$ & $\mathrm{T}$ & $\mathrm{T}$ & $\mathrm{T}$ & $\mathrm{T}$ & $\mathrm{T}$ & $\mathrm{TI}$ \\
\hline
\end{tabular}

Keterangan :

MK = Muara Kenjeran

MM = Muara Morokrembangan

$\mathrm{T}$ = Terdeteksi;
TK = Tengah Kenjeran

$\mathrm{TM}=$ Tengah Morokrembangan

$\mathrm{Tt}=$ Tidak terdeteksi
HK = Hulu Kenjeran.

HM = Hulu Morokrembangan

$\mathrm{X}$ = tidak ada cuplikannya 
Tabel 2. Hasil analisis kandungan logam berat dalam air, sedimen dan enceng gondok dengan waktu iradiasi 12 jam, flux neutron $1.05 \times 10^{11} \mathrm{n} \mathrm{cm}^{-2} \mathrm{dt}^{-1}$, waktu cacah 300 detik di lokasi Sungai Kenjeran

\begin{tabular}{|l|c|c|c|c|}
\hline Lokasi Cuplikan & Unsur & Kadar Air $(\mu \mathrm{g} / \mathrm{ml})$ & Kadar sedimen $(\mu \mathrm{g} / \mathrm{g})$ & Kadar Enceng gondok $(\mu \mathrm{g} / \mathrm{g})$ \\
\hline Muara Kenjeran & $\mathrm{Hg}$ & $1,501 \pm 0.414$ & $16,587 \pm 1.815$ & $5,8 \pm 0,346$ \\
(MK) & $\mathrm{Cd}$ & $\mathrm{O}, 687 \pm 0,229$ & $26,652 \pm 7,858$ & $15,94 \pm 3,284$ \\
& $\mathrm{Cr}$ & $0,004 \pm 0,00 \mathrm{I}$ & $87,082 \pm 8,230$ & $33,672 \pm 1,555$ \\
& $\mathrm{Co}$ & $0,003 \pm 0.0$ & $23.853 \pm 1,284$ & $1,582 \pm 0,044$ \\
\hline Tengah Kenjeran & $\mathrm{Hg}$ & $0,327 \pm 0,061$ & $46,884 \pm 1,745$ & $8,759 \pm 1.28$ \\
(TK) & $\mathrm{Cd}$ & $0,169 \pm 0,062$ & $22,413 \pm 8.917$ & $18,462 \pm 5,762$ \\
& $\mathrm{Cr}$ & $0,067 \pm 0,022$ & $236.567 \pm 5,773$ & $31629 \pm 1,616$ \\
& $\mathrm{Co}$ & $0,011 \pm 0,001$ & $23.047 \pm 0.54$ & $1,503 \pm 0.105$ \\
\hline Hulu Kenjeran & $\mathrm{Hg}$ & $0.590 \pm 0.034$ & $63.181 \pm 5.380$ & $9.733 \pm 1.135$ \\
(HK) & $\mathrm{Cd}$ & $0,525 \pm 0,066$ & $13,470 \pm 3,027$ & $11,308 \pm 1,338$ \\
& $\mathrm{Cr}$ & $0,016 \pm 0,005$ & $124,278 \pm 4.496$ & $25,598 \pm 2,244$ \\
& $\mathrm{Co}$ & $0,0008 \pm 0,0002$ & $22,428 \pm 1,286$ & $7,045 \pm 0,367$ \\
\hline
\end{tabular}

Tabel 3. Hasil analisis kandungan logam berat dalam air, sedimen dan enceng gondok dengan waktu iradiasi 12 jam, flux neutron $1.05 \times 10^{11} \mathrm{n} \mathrm{cm}^{-2} \mathrm{dt}^{-1}$, waktu cacah 300 detik di lokasi Muara, Tengah dan Hulu Kenjeran Morokrembangan.

\begin{tabular}{|l|c|c|c|c|}
\hline \multicolumn{1}{|c|}{ Lokasi Cuplikan } & Unsur & Kadar Air $(\mu \mathrm{g} / \mathrm{ml})$ & Kadar sedimen $(\mu \mathrm{g} / \mathrm{g})$ & $\begin{array}{c}\text { Kadar Enceng gondok } \\
(\mu \mathrm{g} / \mathrm{g})\end{array}$ \\
\hline Muara & $\mathrm{Hg}$ & $0,780 \pm 0,035$ & $7,873 \pm 0,533$ & - \\
Morokrembangan & $\mathrm{Cd}$ & $5,066 \pm 0,739$ & $30,225 \pm 3,381$ & - \\
& $\mathrm{Cr}$ & $0,046 \pm 0,006$ & $48,783 \pm 1,971$ & - \\
& $\mathrm{Co}$ & $0,005 \pm 0,002$ & $16,962 \pm 0,321$ & - \\
\hline Tengah & $\mathrm{Hg}$ & $0,159 \pm 0,013$ & $, 10,333 \pm 1,271$ & $4,866 \pm 0,351$ \\
Morokrembangan & $\mathrm{Cd}$ & $0,084 \pm 0,009$ & $11,091 \pm 4,38$ & $6,113 \pm 0,438$ \\
& $\mathrm{Cr}$ & $0,011 \pm 0,004$ & $69,718 \pm 4,359$ & $23,503 \pm 5,283$ \\
& $\mathrm{Co}$ & $0,001 \pm 0,0001$ & $24,924 \pm 3,442$. & $2,108 \pm 0,225$ \\
\hline Hulu Morokrembangan & $\mathrm{Hg}$ & $0,572 \pm 0,05$ & $15,776 \pm 2,717$ & $3,637 \pm 0,362$ \\
& $\mathrm{Cd}$ & $0,130 \pm 0,017$ & $35,79 \pm 7,249$ & $11,351 \pm 2,503$ \\
& $\mathrm{Cr}$ & $0,016 \pm 0,002$ & $156,711 \pm 4,383$ & $25,960 \pm 2,565$ \\
& $\mathrm{Co}$ & $0,001 \pm 0,00005$ & $19,482 \pm 1,016$ & $0,766 \pm 0,233$ \\
\hline
\end{tabular}

Keterangan : di lokasi muara Morokrembangan cuplikan enceng gondok tidak ada

\section{Analisis Kuantitatif}

Analisis ini hanya dibatasi pada unsur logam berat $\mathrm{Hg}, \mathrm{Cd}$, $\mathrm{Cr}$ dan Co karena logam-logam tersebut akan dibandingkan dengan penelitian sebelumnya.

Analisis kuantitatif air sungai, sedimen dan enceng gondok dari empat unsur dilakukan secara komparatif dengan menggunakan rumus $1-3$ dan diperoleh hasil seperti tabel 2 dan 3 .

Pada Tabel 2 dan 3 hasil analisis kandungan logam berat $\mathrm{Hg}$ pada sedimen di lokasi. sungai Kenjeran bagian hulu (kel
Gading) yang menunjukkan kadar logam berat yang paling tinggi dari 3 lokasi. Tingginya kandungan logam berat $\mathrm{Hg}$ dalam sedimen di Hulu Kenjeran (kel Gading) dengan lokasi lainnya diduga disebabkan adanya aktivitas pemisahan emas secara tradisional di sekitar daerah tersebut. Hal tersebut dipaparkan pada Tabel 1 dengan teridentifikasi unsur $\mathrm{Au}$ (emas) dalam sedimen, enceng gondok dan air.

Berdasarkan dari uji hipotesis perbedaan lokasi (uji f, dengan $\alpha_{0.05}$ ) bahwa pada cuplikan sedimen sungai Kenjeran 
unsur $\mathrm{Hg}$ dan $\mathrm{Cr}$ menunjukkan terdapat pengaruh yang signifikan terhadap perbedaan lokasi cuplikan, Ho ditolak (ada beda nyata), sedangkan unsur Cd dan Co tidak ada pengaruh yang signifikan terhadap perbedaan lokasi cuplikan atau Ho diterima (tidak ada beda nyata). Cuplikan sedimen di Sungai Morokrembangan unsur $\mathrm{Hg}$, Cd dan Co menunjukkan Ho diterima (tidak ada beda nyata), tidak ada pengaruh yang signifikan terhadap perbedaan lokasi cuplikan tersebut, sedangkan unsur $\mathrm{Cr}$ ada pengaruh yang signifikan terhadap perbedaan lokasi cuplikan atau Ho ditolak (ada beda nyata). Jadi tinggi rendahnya kadar unsur $\mathrm{Cr}$ dipengaruhi oleh lokasi pengambilan cuplikan.

Pada Tabel 2 dan 3 dapat dilihat bahwa pada enceng gondok di Sungai Morokrembangan dan Sungai Kenjeran terdeteksi logam berat $\mathrm{Hg}, \mathrm{Cd}, \mathrm{Cr}$ dan Co cukup tinggi. Kandungan logam berat yang tinggi pada sedimen memungkinkan kandungan logam dalam enceng gondok juga tinggi. Pada penelitian ini juga menunjukkan hal yang demikian pada lokasi dengan kandungan sedimen yang tinggi kandungan logam berat dalam enceng gondok juga tinggi. Berdasarkan uji hipotesis (uji f, dengan $\alpha_{0.05}$ ), perbedaan lokasi enceng gondok di Sungai Kenjeran unsur $\mathrm{Hg}$, Cd dan $\mathrm{Cr}$ menunjukkan tidak ada pengaruh yang signifikan terhadap perbedaan lokasi cuplikan, Ho diterima (tidak ada beda nyata) sedangkan unsur Co ada pengaruh yang signifikan terhadap perbedaan lokasi cuplikan, Ho ditolak (ada beda nyata). Berdasarkan data, Tabel 2 dan 3 kandungan logam berat cuplikan air, sedimen dan enceng gondok di sungai Kenjeran pada umumnya lebih tinggi dari pada cuplikan air, sedimen dan enceng gondok Sungai Morokrembangan, berarti sungai Kenjeran lebih tercemar daripada sungai Moro-krembangan. Diduga di daerah aliran sungai Kenjeran jumlah industri, jumlah rumah sakit dan jumlah penduduk lebih padat daripada di daerah aliran sungai
Morokrembangan, atau air limbah buangannya tidak dikelola dengan baik.

Kandungan logam berat dalam penelilian ini (Tabel 2 dan 3) yang tertinggi selalu ditemukan dalam sedimen sungai. Hal ini menunjukkan bahwa akumulasi tertinggi dari logam berat terjadi pada sedimen sungai dan memberikan petunjuk bahwa sebagian besar senyawa pada logam berat yang masuk ke perairan sungai Surabaya berbentuk partikel atau endapan dan hanya sebagian kecil yang terlarut dalam air. Hal ini sesuai dengan teori bahwa logam berat dalam perairan, baik yang berasal dari sungai, laut maupun dari organisme yang hidup dan mati pada fase akhir akan mengendap ke sedimen dasar perairan, sehingga path ways pencemaran sungai adalah mirip dengan pathways pencemaran di pantai ${ }^{(7)}$, yakni :

(air $\rightarrow$ biota $\rightarrow$ sedimen), hal ini akan diperkuat dengan data besaran $F_{B}$ dan $F_{D}$ dalam Tabel 4.

Jika dibandingkan dengan data penelitian pantai Kenjeran oleh Agus Taftazani $2001^{(7)}$ sebagaimana terpapar pada Tabel 5. Logam berat yang terkandung dalam sedimen di lokasi pantai Kenjeran (Tabel 5) lebih rendah dibandingkan dengan sedimen dari Sungai Kenjeran dan Sungai Morokrembangan (Tabel 2 dan 3) karena yang dipantai Kenjeran telah terencerkan oleh air yang digerakkan oleh arus/ombak pantai tersebut. Kadar semua unsur logam berat dalam cuplikan sedimen adalah terbesar, dibandingkan dengan kadar logam dalam kerang, ikan dan air. 
Tabel 4. Hasil analisis kandungan logam berat, faktor bioakumulasi $\left(\mathrm{F}_{\mathrm{B}}\right)$ dan faklor distribusi $\left(\mathrm{F}_{\mathrm{D}}\right)$ dalam air sungai, sedimen dan enceng gondok di lokasi sungai Kenjeran dan sungai Morokrembangan.

\begin{tabular}{|c|c|c|c|}
\hline $\begin{array}{c}\text { Lokasi } \\
\text { Cuplikan }\end{array}$ & Unsur & $\mathrm{F}_{\mathrm{B}}(\mathrm{ml} / \mathrm{g})$ & $F_{D}(\mathrm{ml} / \mathrm{g})$ \\
\hline \multirow{4}{*}{ MK } & Ho & $5.8 \pm 0,346$ & 11,050 \\
\hline & $\mathrm{Cd}$ & $15,94 \pm 3,284$ & 38,794 \\
\hline & $\mathrm{Cr}$ & $33,672 \pm 1,555$ & 21770,5 \\
\hline & Co & $1,582 \pm 0,044$ & 7951.0 \\
\hline \multirow{4}{*}{ TK } & $\mathrm{Hg}$ & $8,759 \pm 1.280$ & 143.376 \\
\hline & $\mathrm{Cd}$ & $18,462 \pm 5,762$ & 132,621 \\
\hline & $\mathrm{Cr}$ & $31.629 \pm 1,616$ & 3530,850 \\
\hline & Co & $1,503 \pm 0,105$ & 2095.181 \\
\hline \multirow{4}{*}{ HK } & $\mathrm{Hg}$ & $9,733 \pm 1.135$ & 107,086 \\
\hline & Cd & $11.308 \pm 1.338$ & 25.657 \\
\hline & $\mathrm{Cr}$ & $25,598 \pm 2.244$ & 7767.37 \\
\hline & Co & $7,045 \pm 0.367$ & 28035.0 \\
\hline \multirow{4}{*}{ MM } & $\mathrm{Hg}$ & - & 10.093 \\
\hline & $\mathrm{Cd}$ & - & 5.966 \\
\hline & $\mathrm{Cr}$ & - & 1060,5 \\
\hline & Co & - & 3392,4 \\
\hline \multirow{4}{*}{$\mathrm{TM}$} & $\mathrm{Hg}$ & 30.566 & 64.987 \\
\hline & Cd & 72,773 & 132,035 \\
\hline & $\mathrm{Cr}$ & 2136,636 & 6338.0 \\
\hline & Co & 2108,0 & 24924.0 \\
\hline \multirow{4}{*}{ HM } & $\mathrm{Hg}$ & 6,358 & 27,580 \\
\hline & Cd & 81,315 & 275.307 \\
\hline & $\mathrm{Cr}$ & 1622,5 & 9794,437 \\
\hline & Co & 766,0 & 19482,0 \\
\hline
\end{tabular}

Keterangan :

Untuk muara Morokrembangan cuplikan enceng gondok tidak ada sehingga tidak dapat dihitung faktor bioakumulasinya.

MK = Muara Kenjeran $\mathrm{HK}=$ Hulu Kenjeran

TK = Tengah Kenjeran

MM = Muara Morokrembangan

$\mathrm{TM}=$ Tcngah Morokrembangan

$\mathrm{HM}=$ Hulu Morokrembangan
Tabel 5. Kadar, $F_{B}$ dan $F_{D}$ logam berat dalam air laut, sedimen, ikan kerapu dan kerang hijau, waktu iradiasi 12 jam, flux neutron $1.05 \times 10^{11} \mathrm{n} \mathrm{cm}^{-2} \mathrm{dt}^{-1}$, waktu cacah 300 detik di lokasi pantai Kenjeran Surabaya $^{(7)}$.

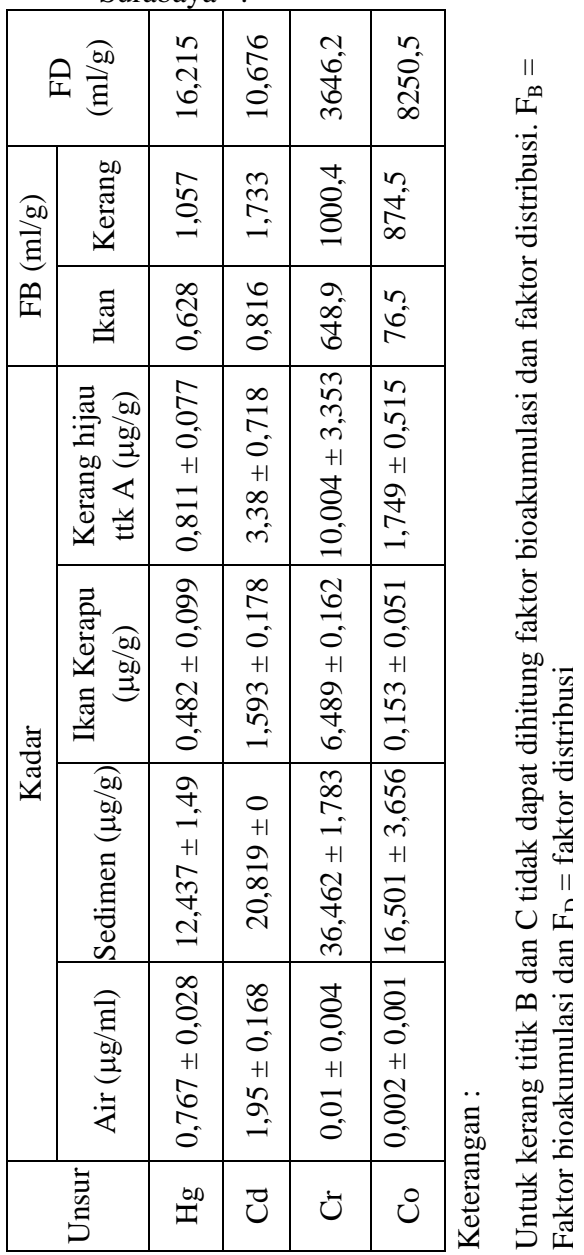

Dari Tabel 4 dan 5 menunjukkan bahwa, konsentrasi setiap logam berat yang dimiliki oleh setiap biota mempunyai konsentrasi yang berbeda. Hal ini selain dipengaruhi oleh kemampuan biota air dalam mongabsorbsi dan mengekskresikan logam yang ada di perairan tersebut, dapat juga. dipengaruhi oleh ikatan kimia dari masing-masing logam yang terlarut di dalam perairan. Logam berat dapat masuk ke 
dalam tubuh biota air melalui permukaan kulit dan melalui insang, sedangkan akumulasi logam berat dalam biota air terjadi pada otot abduktor, insang, mantel, gonad, ginjal dan hati. Perbedaan faktor distribusi $\mathrm{F}_{\mathrm{D}}$ disebabkan oleh kecepatan arus air berbeda. sehingga kesempatan partikel mengendap berbeda.

Berdasarkan tabel tersebut. ternyata faktor bioakumulasi di tiap-tiap lokasi selalu lebih kecil dari faktor distribusi. Hal ini menunjukkan bahwa kemampuan enceng gondok (dan kerang serta ikan) dalam mengakumulasi unsur-unsur logam berat dari lingkungan lebih kecil dibandingkan sedimen.

\section{KESIMPULAN}

Berdasarkan data hasil penelitian maka dapat diambil beberapa kesimpulan sebagai berikut:

1. Dalam cuplikan air sungai, sedimen, enceng gondok, telah terdeteksi unsur Hg. Cd, Cr dan Co.

2. Kandungan logam berat pada cuplikan air sungai, unsur $\mathrm{Hg}$ dan $\mathrm{Cd}$ sudah melebihi ambang batas yang diijinkan untuk keperluan pertanian, perkotaan, industri dan energi tenaga air (air golongan D) menurut baku mutu Kep 02/MEN KLH/I/1988 yaitu unsur $\mathrm{Hg}$ (0,005 ppm) dan Cd (0.01 ppm), sedangkan unsur $\mathrm{Cr}$ dan Co masih di bawah ambang batas yang diijinkan yaitu unsur Cr (1 ppm) dan Co (0,2 ppm).

3. Data kadar unsur logam berat hasil penelitian dalam sedimen dan enceng gondok di semua lokasi penelitian tidak bisa dibandingkan, karena belum ada baku mutunya.

4. Sungai Kenjeran lebih tercemar logam berat $\mathrm{Hg}, \mathrm{Cd}$. $\mathrm{Cr}$ dan $\mathrm{Cd}$ dari pada sungai Morokremhangan.

5. $\mathrm{F}_{\mathrm{B}}$ berbeda dalam setiap jenis cuplikan (enceng gondok di sungai, juga kerang hijau serta ikan krapu di pantai), hal ini dipengaruhi oleh kemampuan biota air dalam mengabsorbsi dan mengekskresikan logam berat yang ada di perairan.

6. $\mathrm{F}_{\mathrm{D}}$ berbeda dalam setiap lokasi dipengaruhi oleh kecepatan arus air atau besar ombak.

7. Konsentrasi logam berat $\mathrm{Hg}, \mathrm{Cd}, \mathrm{Cr}$ dan Co dalam sedimen $>$ biota $>$ air, maka alur pencemaran (path ways) nya sebagai berikut : biota air sedimen.

\section{DAFTAR PUSTAKA}

1. AGUS TAFTAZANI, A. PRAMUDITA, K.,TRI BASUKI., S.WIDAYATI., NGASIFUDIN. The Indonesian Pilot Projects On Environmental Monitornlg and Specimen Bank (EMSB). Proceedings of Indonesia-German Symposium on Environmental Monitoring and Specimen Bank, Yogyakarta-Indonesia, December 12-13 1995.

2. AGUS TAFTAZANI, KRIS TRI BASUKI, MD. SUBAKIR, SISTOJO PRAMUSISWOJO, JHONY WAHYUADI. Evaluasi Kadar Logam Berat Co, Cr, dan Hg Pada Air dan Ikan di Sungai Surabaya Dengan Metode Aktivasi Neutron. Proceeding th 1999 FTUI Seminar-Quality in Research Volume IV. Kampus Universitas Indnesia Depok. 3-6 Agust 1999.

3. DARMONO 1995. Logarn dalam Sistem Biologi Makhluk Hidup, VI Press. Jakarta.

4. ANONIM, 1997. Laporan Penelitian Balai Teknik Kesehatan Lingkungan, Surabaya.

5. ANONIM, 1998. Laporan Penelitian BAPPEDA Tingkat I, Jawa Timur, Surabaya.

6. AGUS TAFTAZANI, SUMINING, SUTANTO WW, KRIS TRI B, GANDEN SUPRIYANTO DAN ABDULLAH. Analisis Kandungan Logam $\mathrm{Hg}, \mathrm{Co}, \mathrm{Cr}$ dan $\mathrm{Cd}$ pada Sedimen dan Eceng Gondok di Sungai Surabaya dengan Metode Pengaktifan Neutron. Prosiding Seminar Nasional I 
Kimia Analisis. Jaringan Kerjasama Kimia Indonesia, Yogyakarta 24-25 Agustus 1999.

7. AGUS TAFTAZANI, SUMINING DAN MUZAKKY. Evaluasi Sebaran Logam Berat dalam Cuplikan Air, Sedimen, Ikan Krapu dan Kerang Hijau di Perairan Pantai Kenjeran Surabaya II. GANENDRA Majalah IPTEK Nuklir. Vol IV. No.1. Januari 2001. Puslitbang Teknologi Maju. BATAN, Jogjakarla.

8. AGUS TAFTAZANI, SUMINING DAN ROSIDI. Analisis Pengaktifan Neutron untuk cuplikan Geologi, Lingkungan Biologi dan Produk Industri. Dipresentasikan pada Seminar Regional Fisika se Jatim, dalam Harlah ke 32 Jurusan Pendidikan Fisika FMIPA-IKIP Malang. Malang 12 Oktober 1996.
9. ANONIM, 1988. SK KEP-02/MENKLH/ 1988. Jakarta.

10. NAREH, M dan SUTARMAN. Metode engukuran Aktivitas Tingkat Rendah, PSPKR-BATAN, Jakarta 1993

11. ERDTMANN, G. and SOYKA. W. The Gamma Ray of the Radionuclides Tables for Applied Gamma Ray Spectrometry. Weinheim, New York, 1979 